\title{
Production of Pectin Lyase by Colletotrichum lindemuthianum in Culture and in Infected Bean (Phaseolus vulgaris) Tissue
}

\author{
By R. L. C. WIJESUNDERA, J. A. BAILEY* AND R. J. W. BYRDE \\ Long Ashton Research Station, Unitersity of Bristol, Long Ashton, Bristol BS18 9AF, UK
}

(Received 15 August 1983; revised 7 October 1983)

Colletotrichum lindemuthianum race $\gamma$ secreted two forms of pectin lyase, having pI values of 8.2 and $9 \cdot 7$, when grown in culture with sodium polypectate or isolated Phaseolus vulgaris hypocotyl cell walls as the main source of carbon. A single form of polygalacturonase was also present in both media. A pectin lyase, with a PI value of 9.7 was detected in necrotic $P$. vulgaris tissue infected with race $\gamma$, but polygalacturonase activity was absent.

\section{INTRODUCTION}

Colletotrichum lindemuthianum (Sacc. et Mgn.) Bri. et Cav. produces large water-soaked lesions on susceptible cultivars of bean, Phaseolus vulgaris $\mathrm{L}$. It is a hemibiotrophic pathogen, whose infection hyphae exhibit an initial period of biotrophic growth, when they grow through plant cell walls and obtain nutrients for growth without killing the infected cells. The initially infected cells eventually die, and the fungus then grows extensively in the dead tissues (necrotrophy), which become extensively macerated as lesions become evident (Bailey, 1982). The present research programme aims to assess the involvement of cell wall-degrading enzymes in both biotrophic and necrotrophic fungal growth and to determine whether changes in enzyme secretion during infection can explain the transition from biotrophy to necrotrophy.

Cell wall-degrading enzymes play a major role in symptom development in many diseases (Bateman \& Basham, 1976) and several, including polygalacturonase, $\alpha$-galactopyranosidase, $\alpha$ arabinofuranosidase, cellulase, $\beta$-xylosidase and protease have been described from $C$. lindemuthianum (English et al., 1971; Anderson \& Albersheim, 1972; Ries \& Albersheim, 1973; Barthé et al., 1981; Cervone et al., 1981). However, except for a brief comment by Cervone et al. (1981), there are no reports of the production of pectin lyase by this pathogen, nor are there any data concerning the presence of any cell wall-degrading enzymes in bean tissues infected by this pathogen.

This paper describes the properties and activity of pectin lyase produced by the race $\gamma$ of $C$. lindemuthianum in different media and in lesions of infected hypocotyl tissue of $P$. vulgaris $\mathrm{cv}$. Kievitsboon Koekoek, with which race $\gamma$ is compatible.

\section{METHODS}

Preparation of cell walls of Phaseolus i ulgaris. Seedlings of $P$. vulgaris cv. Kievitsboon Koekoek were grown in moist vermiculite in a growth cabinet (Fisons 9600 ) at $25 \pm 0.5{ }^{\circ} \mathrm{C}, 80 \%$ relative humidity, $40 \mu \mathrm{E} \mathrm{m}^{-2} \mathrm{~s}^{-1}$ photon flux density. $16 \mathrm{~h}$ photoperiod. The seedlings were harvested $10 \mathrm{~d}$ after sowing, following a period of $36 \mathrm{~h}$ in complete darkness. The hypocotyls were frozen and cell walls isolated according to the method described by English et al. (1971). except that $500 \mathrm{~mm}$-potassium phosphate buffer was used for extraction instead of $100 \mathrm{~mm}$ buffer, to minimize the presence of ionic proteins (Jones et al., 1972). The yield of cell walls was approximately $2 \cdot 5^{\circ}$ of tissue fresh weight. Starch was not detected in the isolated cell wall preparation by an iodine test.

Fungal culture and preparation of nutrient media. Race $\gamma$ of Colletotrichum lindemuthianum (Rowell \& Bailey,

Abbretiations: PL, pectin lyase: TBA, thiobarbituric acid. 
1983), was grown in an ammonium tartrate medium (Byrde \& Fielding, 1968) containing sodium polypectate or isolated cells walls $\left(0.5 \mathrm{~g} \mathrm{l}^{-1}\right)$ as its main source of carbon. All the media were autoclaved for $15 \mathrm{~min}$ at $121^{\circ} \mathrm{C}$.

One litre glass 'penicillin' flasks containing $250 \mathrm{ml}$ medium were inoculated with $1 \mathrm{ml}$ of a suspension of spores (containing about $10^{6}$ spores), obtained from 7 to 8 -d-old sporulating cultures of $C$. lindemuthianum grown as described by Bailey \& Deverall (1971). The inoculated media were incubated without shaking at $17 \pm 1{ }^{\circ} \mathrm{C}$, under a 'black' fluorescent light (F 8T5, GTE Sylvania Inc., Lighting Products, Denver, Colo., USA) with a $12 \mathrm{~h}$ photoperiod.

The cultures were harvested $12 \mathrm{~d}$ after inoculation by filtering through Whatman no. 1 filter paper. The filtrate was dialysed against distilled water for $48 \mathrm{~h}$ at $4{ }^{\circ} \mathrm{C}$, and was concentrated $(\times 10)$ by freeze drying.

Inoculation of the seedlings. Seedlings of $P$. vulgaris cv. Kievitsboon Koekoek were grown for $7 \mathrm{~d}$ in the illuminated growth cabinet described above. The hypocotyl segments were inoculated with $C$. lindemuthianum and incubated at $16^{\circ} \mathrm{C}$ (Rowell \& Bailey, 1983).

Extraction of enzymes from infected plant material. Seven to eight days after inoculation, brown water-soaked lesions were visible on the hypocotyls. At this stage, the entire hypocotyls were harvested, frozen immediately, and freeze dried. The dry tissue was extracted and prepared for iso-electric focusing as described by Fielding (1981), although $1.0 \mathrm{M}-\mathrm{NaCl}$ was used instead of $0.1 \mathrm{M}-\mathrm{KCl}$, since in preliminary experiments, extracts prepared with this reagent gave greater enzyme activity.

Iso-electric focusing. Iso-electric focusing was carried out in an LKB $110 \mathrm{ml}$ column using LKB ampholines of $\mathrm{pH}$ range $3 \cdot 5-10 \cdot 0$, in a linear sucrose gradient at $10^{\circ} \mathrm{C}$ for $48 \mathrm{~h}$ (Laborda et al., 1973). The column was eluted and $3.0 \mathrm{ml}$ fractions were collected using a peristaltic pump at $120 \mathrm{ml} \mathrm{h}^{-1}$. The $\mathrm{pH}$ of the fractions was recorded immediately afterwards and the enzyme activity of the fractions was measured.

Enzyme assays. Pectin lyase (PL; EC 4.2.2.10) activity was measured spectrophotometrically (Byrde \& Fielding, 1968). The standard reaction mixture comprised $3.0 \mathrm{ml} 0.25 \%(\mathrm{w} / \mathrm{v})$ citrus pectin in $0.1 \mathrm{M}-\mathrm{Tris} / \mathrm{HCl}$ buffer of appropriate $\mathrm{pH}$ and $0.1 \mathrm{ml}$ enzyme solution. The absorbance at $240 \mathrm{~nm}$ was read immediately after the addition of the enzyme sample and after an incubation period at $30^{\circ} \mathrm{C}$. One unit of enzyme activity is defined as that amount which produces $1 \mu \mathrm{mol}$ unsaturated uronide in $1 \mathrm{~min}$, based on the molar absorption for the product of 4600 (Hislop et al., 1979). PL activity was also examined using the thiobarbituric acid (TBA) method (Ayers $e t$ al., 1966). After specified reaction periods, $1.0 \mathrm{ml}$ samples of the reaction mixture described above, were added to $6.0 \mathrm{ml}$ TBA reagent $(5.0 \mathrm{ml} 0.01 \mathrm{M}-\mathrm{TBA}$ and $1.0 \mathrm{ml} \mathrm{l} \mathrm{M}-\mathrm{HCl})$, and kept in a boiling water bath for $60 \mathrm{~min}$. After cooling, the absorption was read at $550 \mathrm{~nm}$.

Polygalaturonase (EC 3.2.1.15) was estimated by the cup-plate assay method of Dingle et al. (1953) using a sodium polypectate-agar gel. Activities are expressed relative to an aqueous solution $\left(1 \mathrm{mg} \mathrm{ml}^{-1}\right)$ of Pectinol $10 \mathrm{M}$ which was defined as having 100 units of polygalacturonase activity $\mathrm{ml}^{-1}$.

The polygalacturonase activity in extracts of infected lesions was also determined by measuring the decrease in viscosity of a $1 \%(\mathrm{w} / \mathrm{v})$ aqueous solution of sodium polypectate at $\mathrm{pH} 5 \cdot 0$, using a $0 \cdot 1 \mathrm{M}$-sodium acetate buffer in an Ostwald viscometer at $25^{\circ} \mathrm{C}$ (Fielding \& Byrde, 1969).

Molecular weight determinations. Molecular weights were determined as described by Andrews (1964), using a column of Sephadex G-150 or Sephadex G-100, eluted with Tris/HCl buffer (0.05 $\mathrm{M}, \mathrm{pH} 7.6)$, plus $0.1 \mathrm{M}-\mathrm{KCl}$ and calibrated with the following marker proteins: serum albumin (both monomer and dimer in Sephadex G-150), egg albumin, trypsin inhibitor and cytochrome $c$.

Effect of heat and pH on enzyme activity. Heat inactivation was studied by placing enzyme samples ( $5 \mathrm{ml})$ in testtubes maintained in a water bath at desired temperatures for $10 \mathrm{~min}$. The tubes were cooled rapidly in cold water $\left(12{ }^{\circ} \mathrm{C}\right)$ and the contents then assayed for enzyme activity (Spalding \& Abdul-Baki, 1973). Borate, Tris and phosphate buffer systems were used to determine the optimum pH for enzyme activity.

Chemicals. Sources were as follows: citrus pectin, H.P. Bulmer Ltd, Hereford, UK ; polygalacturonic acid and the marker proteins, Sigma; sodium polypectate, Exchange Lemon Product Co., California, USA; Pectinol 10M, Rohm \& Haas Ltd, Philadelphia, USA. All other chemicals were of at least 'Laboratory Reagent' grade and, when available, 'Analar' chemicals were used.

\section{RESULTS}

\section{Enzyme activity in culture filtrates}

Filtrates from 12-d-old cultures of $C$. lindemuthianum grown with sodium polypectate as the main carbon source had PL activity. When the culture filtrate was electrofocused (Fig. $1 a$ ), two distinct peaks of activity were present. A minor peak was present at pI 8.2 (PL I) and the major peak at pI 9.7 (PL II).

PL activity was also present in filtrates from cultures where cell walls isolated from hypocotyls of $P$. vulgaris were the main sources of carbon. Iso-electric focusing again produced two peaks of 


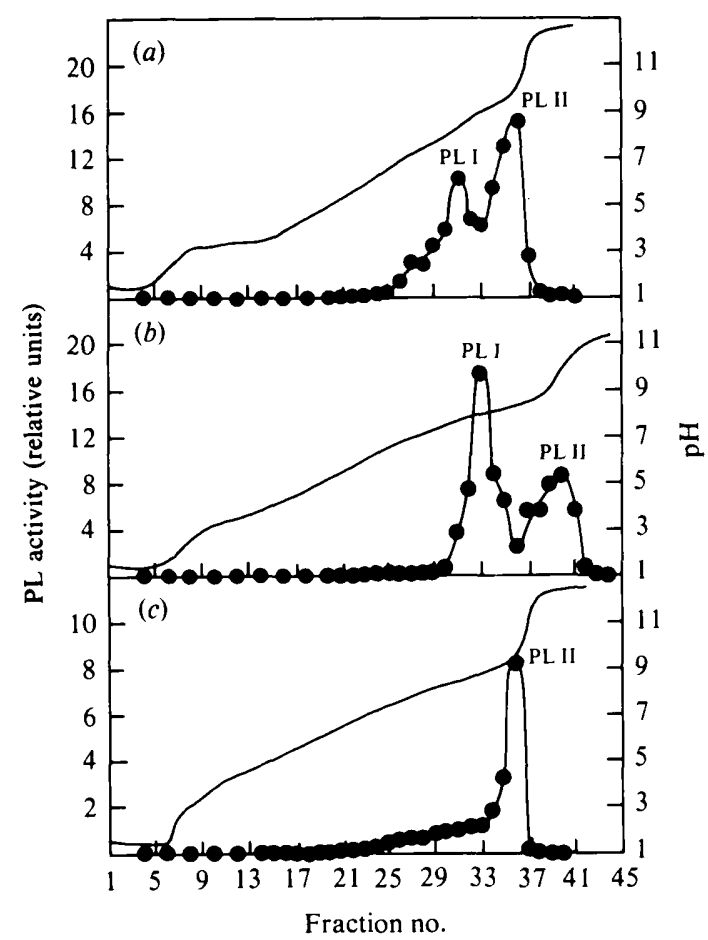

Fig. 1. Iso-electric focusing of culture filtrates of Colletotrichum lindemuthianum. (a) Sodium polypectate medium; $(b)$ cell wall medium; and $(c)$ extracts of lesions from infected bean hypocotyls. -, pH gradient;, $\mathrm{PL}$ activity measured as change in absorbance at $240 \mathrm{~nm}$.

enzyme activity (Fig. $1 b$ ). In these filtrates, however, the major peak of activity was at pI $8 \cdot 2(\mathrm{PL}$ I), with much less activity at pI $9 \cdot 7$ (PL II).

Culture filtrates from both media also showed a single peak of polygalacturonase activity at pI 9.3 (not shown). Lyase activity was also detected in both culture filtrates when polygalacturonic acid was used as the substrate in place of citrus pectin.

\section{Effect of calcium ions on pectin lyase activity}

$\mathrm{CaCl}_{2}$ was added to reaction mixtures to give concentrations between 0 and $0.06 \mathrm{M}$ (Cooper $e t$ al., 1978), and the activity of PL I and PL II, i.e. those obtained from iso-electric focusing, was measured. Neither of the forms had an absolute requirement for calcium ions for activity, but their activity increased with the increase in calcium ion concentration. PL I from both media showed maximum activity at $0.001 \mathrm{M}$ and the activity decreased thereafter. PL II had its maximum activity at $0.05 \mathrm{M}$-calcium ion concentration. PL II seemed more calcium dependent than PL I. Both forms of the enzyme isolated from the sodium polypectate medium showed a greater increase in activity with the increase in calcium ion concentration than their respective forms produced in the cell wall medium.

\section{Effect of $\mathrm{pH}$ and temperature inactivation}

All the forms of PL showed maximum activity under alkaline conditions. PL I from sodium polypectate or cell wall medium had its optimum at $\mathrm{pH} 9.3$ or at $\mathrm{pH} 8.8$, respectively. PL II from both media had optimum activity at pH $9 \cdot 8$ (Fig. $2 a$ ).

Treatment of the enzyme at $30^{\circ} \mathrm{C}$ for 10 min increased its activity slightly compared with that at $20^{\circ} \mathrm{C}$, but at temperatures higher than $30^{\circ} \mathrm{C}$ activity was reduced. At $60^{\circ} \mathrm{C}$, activity of all forms of the enzyme showed a decrease of nearly $75 \%$, although some activity remained even after treatment at $70^{\circ} \mathrm{C}$. 

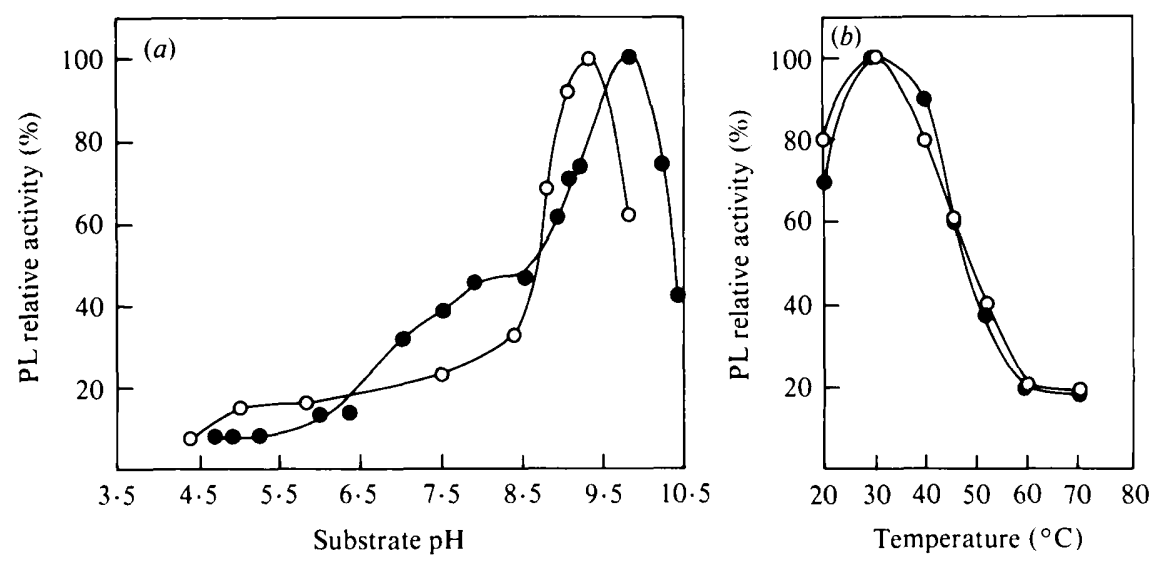

Fig. 2. Effect of $\mathrm{pH}(a)$ and temperature $(b)$ on the activity of the two forms of PL from a sodium polypectate culture filtrate. $\mathrm{O}, \mathrm{PL}$ I;, PL II. PL activity was measured using change in absorbance at $240 \mathrm{~nm}$. In both instances a similar pattern of activity was also obtained for the two forms of PL from the cell wall medium.

\section{Enzyme activity in infected necrotic tissue}

Iso-electric focusing of extracts of lesion tissue in bean hypocotyls infected with race $\gamma$ produced a single peak of PL activity, focusing at pI 9.7, with a shoulder in the pI range 7.9 to 8.5 (Fig. $1 c$ ). No PL activity was detected in extracts of healthy $P$. vulgaris hypocotyl tissue.

Polygalacturonase activity could not be detected in the extracts of lesions either by the plate assay or by viscometry. In the plate assay of the iso-electrically focused fractions from extracts, white opaque rings developed between pI 8.0 and 10.5 instead of the usual clear rings obtained with similar fractions from culture filtrates. After autoclaving at $121^{\circ} \mathrm{C}$ for $15 \mathrm{~min}$, the fractions from the extracts still produced the opaque rings, whilst no rings were produced by autoclaved fractions from the culture filtrate.

\section{Molecular weights of the multiple forms of pectin lyase}

The molecular weights of the forms of the enzyme from the culture filtrates were determined in two experiments using the Sephadex G-150 column. PL I from the sodium polypectate medium had a mean molecular weight of 23000 , whilst the molecular weight of PL I from the cell wall medium was 23500 . For PL II the estimated mean molecular weights from sodium polypectate and the cell wall medium, were 28500 and 27000 , respectively. The molecular weight of the PL II (pI 9.7) from tissue extracts was determined using the Sephadex G-100 column, as 24500 .

\section{DISCUSSION}

Colletotrichum lindemuthianum secreted two forms of pectin lyase (PL I and PL II) in artificial media. Many plant pathogenic micro-organisms produce multiple forms of individual types of pectolytic enzymes (Hancock, 1976; Byrde, 1982), and the presence of multiple forms of an enzyme could confer an added advantage to the pathogen, because some forms may be more stable in the host than others (Byrde \& Archer, 1977).

On the basis of the characters studied, i.e. molecular weights, pH activity, heat stability, calcium dependency and iso-electric points, the fungus seems to secrete the same two forms of the enzyme when growing on either pectate or on isolated cell walls as the main carbon source. However, the relative amounts of the two forms obtained from the two media differed. At the time of harvesting PL I was the major form from the cell wall medium, whereas PL II was the major form from the sodium polypectate medium. Though the activity of all the forms was stimulated by calcium ions, this enhancement was less pronounced in the forms from the cell 
wall medium. This could be attributed to the presence of calcium ions in isolated cell walls (Cooper et al., 1978) which may reduce the effect of added calcium.

One form of pectin lyase (PL II) was predominant in necrotic lesions, although there were indications of very low PL I activity.

The inability to detect polygalacturonase activity in extracts of lesion tissue contrasts with the high PL activity therein and with the presence of both enzymes in culture filtrates. This finding needs an explanation; it also emphasizes that PL is more likely to be of importance in pathogenesis expecially during necrotrophic pathogen growth. Further studies will assess the regulation of PL activity during the biotrophic stage of the disease and during the transition from biotrophy to necrotrophy.

R. L. C. Wijesundera wishes to thank the Association of Commonwealth Universities in the UK for the award of a Commonwealth Scholarship, during the tenure of which this work was carried out. We are indebted to A. H. Fielding for iso-electric focusing and gel-filtration.

\section{REFERENCES}

Anderson, A. J. \& Albersheim, P. (1972). Hostpathogen interactions. V. Comparison of the abilities of the proteins isolated from 3 varieties of Phaseolus vulgaris to inhibit endo-polygalacturonase secreted by 3 races of Colletotrichum lindemuthianum. Physiological Plant Pathology 2, 339-346.

ANDREWS, P. (1964). Estimation of the molecular weight of proteins by Sephadex gel filtration. Biochemical Journal 91, 222-233.

Ayers, W. A., Papavizas, G. C. \& Diem, A. F. (1966). Polygalacturonate trans-eliminase and polygalacturonase production by Rhizoctonia solani. Phytopatho$\log y$ 56, 1006-1011.

BaIley, J. A. (1982). Physiological and biochemical events associated with the expression of resistance to disease. In Active Defense Mechanisms in Plants, pp. 39-65. Edited by R. K. S. Wood. London \& New York: Plenum Press.

Bailey, J. A. \& DeVerall, B. J. (1971). Formation and activity of phaseollin in the interaction between bean hypocotyls (Phaseolus vulgaris) and physiological races of Colletotrichum lindemuthianum. Physiological Plant Pathology 1, 435-446.

Barthé, J. P., Cantenys, D. \& Touzé, A. (1981). Purification and characterization of two polygalacturonases secreted by Colletotrichum lindemuthianum. Phytopathologische Zeitschrift 100, 162-171.

Bateman, D. F. \& Basham, H. G. (1976). Degradation of plant cell walls and membranes by microbial enzymes. In Encyclopaedia of Plant Physiology, vol. I, pp. 316-355. Edited by P. H. Williams and R. Heitefuss. Berlin, Heidelberg \& New York: Springer-Verlag.

Byrde, R. J. W. (1982). Presidential Address. Fungal 'Pectinases': from ribosomes to plant cell wall. Transactions of the British Mycological Society 79, 114.

Byrde, R. J. W. \& ARChER, S. A. (1977). Host inhibition or modification of extra-cellular enzymes of pathogens. In Cell Wall Biochemistry Related to Specificity in Host-Plant Interactions, pp. 213-245. Edited by B. Solheim \& J. Raa. Tromsø: Universitetsforlaget.

Byrde, R. J. W. \& Fielding, A. H. (1968). Pectin methyl-trans-eliminase as the maceration factor of Sclerotinia fractigena and its significance in brown rot of apple. Journal of General Microbiology 52, 287297.

Cervone, F., Anderbhan, T., Coutts, R. H. A. \& WoOD, R. K. S. (1981). Effects of french bean tissue on Colletotrichum lindemuthianum polygalacturonase. Phytopathologische Zeitschrift 102, 238-246.

COOPER, R. M., RAmkin, B. \& WoOd, R. K. S. (1978). Cell wall degrading enzymes of vascular wilt fungi II. Properties and modes of action of polysaccharidases of Verticillium albo-atrum and Fusarium oxysporum f. sp. lycopersici. Physiological Plant Pathology 13, 107-134.

Dingle, J., Reid, W. W. \& Solomons, G. L. (1953). The enzymatic degradation of pectin and other polysaccharides. II. Application of the cup plate assay to the estimation of enzymes. Journal of the Science of Food and Agriculture 4, 149-153.

English, P. D., Jurale, B. J. \& Albersheim, P. (1971). Host-Pathogen interactions. II. Parameters affecting polysaccharide degrading enzyme secretion by Colletotrichum lindemuthianum grown in culture. Plant Physiology 47, 1-6.

FieldiNG, A. H. (1981). Natural inhibitors of fungal polygalacturonases in infected fruit tissue. Journal of General Microbiology 123, 377-381.

FieldiNG, A. H. \& BYRDE, R. J. W. (1969). The partial purification and properties of endopolygalacturonase and $\alpha-\mathrm{L}$-arabinofuranosidase secreted by Sclerotinia fructigena. Journal of General Microbiology 58, 73-84.

HANCOCK, J. G. (1976). Multiple forms of endo-pectate lyase formed in culture and in infected squash hypocotyls by Hyphomyces solani f.sp. cucurbitae. Phytopathology 66, 40-45.

Hislop, E. C., Keon, J. P. R. \& Fielding, A. H. (1979). Effect of pectin lyase from Monilinia fructigena on viability, ultrastructure and localization of acid phosphatase of cultured apple cells. Physiological Plant Pathology 14, 371-381.

Jones, T. M., Anderson, A. J. \& Albersheim, P. (1972). Host-Pathogen interactions. IV. Studies on the polysaccharide degrading enzymes secreted by Fusarium oxysporum f.sp. lycopersici. Physiological Plant Pathology 2, 153-166.

Laborda, F., Fielding, A. H. \& Byrde, R. J. W. (1973). Extra- and intracellular $\alpha$-L-arabinofuranosi- 
dase of Sclerotinia fructigena. Journal of General Microbiology 79, 321-329.

Ries, S. M. \& Albersheim, P. (1973). Purification of a protease secreted by Colletotrichum lindemuthianum. Phytopathology 63, 625-629.

Rowell, P. M. \& BAILEY, J. A. (1983). The influence of cotyledons, roots and leaves on the susceptibility of hypocotyls of bean (Phaseolus vulgaris) to compatible races of Colletotrichum lindemuthianum. Physiological Plant Pathology 23, 245-256.

SPAlding, D. H. \& ABDUL-BAKI, A. A. (1973). In vitro and in vivo production of pectin lyase by Penicillium expansum. Phytopathology 63, 231-235. 